ШИЛОВ Владимир Викторович - кандидат исторических наук, доцент; заведующий кафедрой общенаучных дисциплин Березниковского филиала Пермского национального исследовательского политехнического университета (618400, Россия, Пермский край, г. Березники, ул. Химиков, 10, каб. 205; vvs595959@таil.ru); член правления Российского общества социологов (Пермское отделение)

\title{
ФЕНОМЕН ДВУХ РОССИЙСКИХ ОЛИГАРХОВ Часть 2
}

Аннотация. В статье рассматривается профессиональная и общественная деятельность двух богатейших людей России: досоветского периода (И.И. Любимов) и постсоветской эпохи (В.В. Тетюхин). Автор приводит примеры ответственного отношения к социальным проблемам рабочих и служащих возглавляемых ими сложных производств, готовности бескорыстно финансировать социально значимые проекты, мыслить как государственными, так и высокими гуманными общечеловеческими категориями.

Ключевые слова: первоначальный капитал, образование, стагнация, экономический кризис, эффективный менеджер, социально ответственный бизнес, меценатство, роль личности в истории

B конце XX в. Россия вновь вступила в эпоху рыночных отношений. 19 ноября 1986 г. Верховный Совет СССР принял закон «Об индивидуальной трудовой деятельности», а 26 мая 1988 г. был принят закон СССР «О кооперации в СССР» (этот день сегодня отмечается как День российского предпринимательства). Вскоре и частная собственность была закреплена законом в Конституции РФ 1993 г. (ст. 35).

Тем не менее значительная часть граждан современной России ностальгируют по временам СССР, где не было частной собственности, а предпринимательство считалось «преступным деянием». Молодежь часто имеет мифологическое представление о советской эпохе [Шилов 2019: 146], но одной из причин неприятия современного российского капитализма является появление сверхбогатых людей, которые не только с трудом могут объяснить источник заработанных ими миллиардов (в долларах США), но и часто демонстративно проводят «ярмарки тщеславия», что и вызывает острый негатив у соотечественников.

Бывший дипломат, пресс-секретарь президента РФ (1992-1995), известный колумнист газеты «Аргументы и факты» В.В. Костиков в 2020 г. в одной из своих публикаций посетовал: «Именно в разгар коронавирусного кризиса в США “некий” еще недавно малоизвестный частный предприниматель Илон Маск обеспечивает запуск частного космического корабля и прекращает зависимость США от российских ракет. Илон Маск не академик, не Курчатов, не Сахаров. Он частный предприниматель, по образованию инженер. Ему 48 лет. Компанию SpaceX основал 18 лет назад, вложив в нее 100 млн собственных долларов. Покупкой яхт и зарубежных дворцов не прославился. В олигархах не числится» 1 .

В.В. Костиков не объясняет понятие «олигарх», но подтекст явно негативный. Автор этих строк под термином «олигарх» условно и с долей иронии понимает тех богатых россиян, которые представлены в списке богатейших людей мира по версии американского финансово-экономического журнала Forbes.

1 Костиков В.В. 2020. Кто выйдет в дамки? - Аргументы и факты. № 25(2066). 1723 июня. С. 5. 
В РФ в XXI в. тоже есть сверхбогатые люди, которые не уступают по своей прогрессивной роли для социума тому же Илону Маску. Речь об одном из таких российских «олигархов», чья жизнь и профессиональная деятельность достойны уважения, восхищения и служат хорошим примером для подражания для других российских «олигархов», и пойдет ниже.

Герой нашего исследования, человек из списка Forbes - В.В. Тетюхин (19322019). Воспоминания и документы о его деятельности, которые и были использованы автором ${ }^{1}$, бережно хранятся в корпоративном Березниковском производственно-историческом музее АВИСМА (БПИМА) ПАО «Корпорация ВСМПО-АВИСМА».

Владислав Валентинович Тетюхин родился 29 ноября 1932 г. в Москве. В 1956 г. окончил Московский институт стали и сплавов (МИСиС) по специальности «инженер-металлург» и после окончания по распределению попал на Верхнесалдинский металлообрабатывающий завод в г. Верхняя Салда Свердловской обл., где сразу включился в работу по налаживанию сложнейшего производства титана.

В том же 1956 г. на заводе № 95 в Верхней Салде началось освоение технологии производств труб, титановых профилей, производства штамповок и поковок из титановых сплавов. 17 февраля 1957 г. был выплавлен первый титановый слиток сплава ВТ 1-1 массой 4 кг и диаметром 100 мм [Ежов 2014: 48], который сегодня можно видеть в экспозиции корпоративного музея. Вел эту уже историческую плавку именно В.В. Тетюхин (непосредственное участие в ее подготовке принимали также А.Л. Андреев, Ю.А. Кунцев, Ю.М. Прилуцких, А.Н. Щетников, П.Г. Павлов).

К началу 1960-х гг. ученые, ИТР, рабочие достойно справились с архисложной задачей - освоением и выпуском на Среднем Урале нового цветного металла - титана - в промышленных масштабах. И несмотря на то что США на 9 лет раньше начали промышленное производство титана, через полтора десятка лет, как начали его производить, СССР вышел в лидеры по объемам и качеству этой важной стратегической продукции.

На ВСМПО за два десятка лет Владислав Валентинович прошел все ступеньки карьерной лестницы - от мастера до заместителя главного металлурга по титановому производству. Стал он и добротным ученым: кандидат технических наук (1965), доктор технических наук (1975). Примечательно, что в списке докладчиков Первого Всемирного конгресса по титану, который состоялся в 1968 г. в Лондоне, значился Владислав Валентинович Тетюхин.

Из-за болезни отца В.В. Тетюхин в 1976 г. вернулся в Москву, где работал начальником сектора Всесоюзного научно-исследовательского института авиационных материалов (ВИАМ), отвечал за надежность титановых сплавов в авиации, ракетостроении и космической технике.

В.В. Тетюхин всегда работал с полной отдачей, обладая потрясающей работоспособностью. Он является автором 131 изобретения и около 100 научно-технических публикаций в серьезных академических изданиях [Тетюхин 1993: 12]. Вполне заслужено он стал лауреатом Ленинской премии (1960) и был награжден советскими и российскими орденами.

После распада СССР системный российский кризис сказался и на ВСМПО, хотя оно с 1957 г. являлось крупнейшим поставщиком полуфабрикатов из титана для аэрокосмической, военной промышленности и судостроения.

\footnotetext{
1 Автор приносит благодарность начальнику пресс-центра филиала АВИСМА ПАО «Корпорация ВСМПО-АВИСМА» Елене Юрьевне Сажиной и руководителю музея БПИМА Елене Сергеевне Богачук за предоставленные материалы.
} 
С января 1989 г. объединение стало работать в условиях хозрасчета, а с января 1990 г. становится арендным предприятием. Но трудности нарастали.

Тому были объективные причины. К началу 1991 г. Советский Союз был самым крупным производителем титана в мире. На предприятиях СССР в год изготавливалось около 90 тыс. т титановой губки и 100 тыс. т слитков, что было в 1,5 больше, чем на всех предприятиях США, Европы и Японии.

В Советском Союзе был единый комплекс по производству титана, который состоял из четырех заводов. Комплекс строился в соответствии с наиболее рациональной технологией производства. Три завода производили титановую губку - Березниковский (Урал), Запорожский (Украина), Усть-Каменогорский (Казахстан).

Производственная губка поступала на завод в г. Верхняя Салда (Урал, Свердловская обл.), где полуфабрикат перерабатывался в слитки и заготовки. Затем изделия поступали на авиационные, моторостроительные и судостроительные заводы.

В советский период на Среднем Урале располагались крупнейшие предприятия (даже по мировым меркам), и между ними существовали довольно жесткие технологические и организационные связи, поэтому на них так тяжело и отразился распад СССР: все налаженные связи с другими регионами практически прекратили существование, а новая нормативно-правовая база (договора, контракты с поставщиками сырья и сбыта продукции) только начинала формироваться.

О конце 1980-х гг. В.В. Тетюхин говорил: «В конце восьмидесятых началось падение всей экономики СССР и нашего производства, в частности... Хотя это поначалу не выражалось в цифрах. Связано это было с тем, что, во-первых, наша экономика была очень слабой по отношению к мировой, во-вторых, началась конверсия. Мы работали больше, чем на семьдесят процентов, на авиапром и оборонку. Это очень серьезно. Вскоре на заводе начался процесс, напоминающий гражданскую войну: разруха... и отсутствие полнейшей перспективы... Руководство не понимало, что творится, куда все идет, как этому противостоять. Тогда было решено пригласить меня. Честно, не очень понимаю, почему был сделан такой выбор».

Титано-магниевые сплавы в больших масштабах использовались в стратегически важных отраслях, обеспечивающих безопасность страны, но в начале 1990-х гг. практически полностью прекратились заказы со стороны государства на авиационную и оборонную технику. В 1992 г. производство титановой губки снизилось на 14\%, а за 9 месяцев 1993 г. упало еще на $30 \%$.

Вот поэтому в начале 1990 -х гг. В.В. Тетюхина как известного тогда уже металлурга, ответственного и принципиального руководителя снова пригласили в Верхнюю Салду. Так он сам вспоминал: «Приехали ребята из Салды и сказали: возвращайся обратно. Ситуация критическая».

В 1992 г. Владислав Валентинович стал директором и акционером завода. Пост гендиректора он оставил только в 2008 г. Забегая вперед, заметим, что, уйдя на пенсию, он с 2009 г. оставался советником гендиректора по науке и технологии, членом совета директоров и стал известным филантропом и меценатом.

В тяжелейшие 1990-е гг. В.В. Тетюхину пришлось в жизни как никогда тяжело. Сам Владислав Валентинович вспоминал: «В лихие 90-е гг. я просыпался ночью в холодном поту, не зная, чем платить зарплату рабочим - 22 тысячи из 50 тысяч жителей Верхней Салды. Заказы на титан сократились в 30 раз, и мы были вынуждены делать все, что можно продать, - какие-то колеса, посуду, лопаты» 1 .

\footnotetext{
1 Сварцевич В. 2016. Хозяин «Титановой долины». - Аргументы и факты (приложение «Деловая среда»). № 28. С. 14.
} 
Предприятие в те годы было полностью самостоятельным акционерным обществом, поэтому рассчитывать на помощь государства не приходилось. Все зависело от инициативы и умения. И самое главное, В.В. Тетюхину удалось сохранить кадровый состав.

Несмотря на тяжелое состояние российской экономики в целом, директор ВСМПО не растерялся и начал искать новые рынки сбыта титана. Владислав Валентинович объехал почти все авиационные компании США, был даже в $N A S A$. В конце концов ему удалось найти партнеров и наладить устойчивую деятельность завода. Начали с поставок титановых слитков для компаний, изготовляющих штамповки, потом постепенно перешли на индивидуальные заказы для Boeing и Airbus (крупнейшие в мире производители авиационной техники).

Забавный случай, связанный с его непритязательностью, до сих пор рассказывают салдинцы про одну его поездку на «Боинг». В.В. Тетюхин почти всю свою жизнь ходил в простой, удобной для него советской одежде. И вот, будучи в приемной «Боинга» в вареной джинсовой куртке, купленной где-то по случаю на Рижском рынке в Москве, он был остановлен изумленной охранной. Дресс-код «русского предпринимателя» явно не соответствовал важному мероприятию в более чем солидной фирме.

Только после того, как лично вышел гендиректор «Боинга» и сказал: «Да это же сам мистер Тетюхин!», к русскому промышленнику сразу стали услужливо обращаться: «Мистер Тетюхин, милости просим!» Впрочем, в дальнейшем «дресс-код» в одежде он в основном соблюдал, дабы не шокировать отечественное и зарубежное «бизнес-сообщество», да и российских руководителей высшего эшелона.

Возможно, вышеприведенный случай в корпорации Boeing несколько мифологизирован, но точно известно, что, став впоследствии богатейшим человеком (153-я строка в списке Forbes), В.В. Тетюхин до конца своих дней жил в обыкновенной трехэтажке в Верхней Салде 1930-х гг. постройки. А на вопрос, почему не приобретет себе более достойное жилье, отвечал просто: «Мужики не поймут». То есть, жил он среди простых людей и как простой человек. Не случайно его называли «наш Валентиныч», «народный миллиардер», «советский святой».

Репутация любой компании - это фундаментальный инструмент отношений между партнерами, и безупречная репутация в бизнесе зарабатывается годами. Даже в трудные для наших металлургов годы, на рубеже XX-XXI вв., когда начиналось время становления сложных производственных международных связей, руководство вело себя с истинным благородством. Приведем пример.

Первый международный контракт уральские производители титана заключили с корпорацией «Боинг» в 1998 г. - на 16\% поставок титана. В.В. Тетюхин при этом вспоминал: «Когда в 2001 году террористы взорвали в США международный торговый центр, американцы сократили поставки титана. У завода был контракт, по которому в этом случае можно получить неустойку. Многие компании так и поступили, а мы заявили “Боингу”, что своих партнеров в беде не бросаем, и наш процент поставок стал повышаться до $50 \%$ от потребности корпорации в нашем титане» 1 .

Разумеется, долгосрочные контракты уральские производители цветных металлов заключали не только с иностранными потребителями, но и с отечественными. В 2012 г. такие соглашения были заключены с холдингом ПАО

\footnotetext{
1 Сварцевич В. 2016. Хозяин «Титановой долины». - Аргументы и факты (приложение «Деловая среда»). № 28. С. 14.
} 
«Компания «Сухой» (боевые и гражданские самолеты марки «Су» и «Бе») и АО «ОДК-Пермские моторы» (производитель авиадвигателей, промышленных газотурбинных установок для электростанций и транспортировки газа; пермские авиадвигатели установлены на самолетах Ил-96-300, Ил-96400Т, Ил-76, Ту-204/214).

Именно самолеты Ту-204/214 и Ил-96-300 с пермскими двигателями ПС-90А составляют основу летного парка специального летного отряда «Россия», обслуживающего первых лиц государства. Продукцию ВСМПО-АВИСМА активно использует и холдинг «Вертолеты России» для реализации таких проектов, как Ми-8/17, Ка-52, «Ансат», Ка-226Т и др.

Вернемся в трудные 90-е гг. ХХ столетия. В 1997-1998 гг. В.В. Тетюхин совместно с В.И. Брештом при участии австрийского инвестиционного банка Creditanstalt и американского инвестора Кеннета Дарта приобрел 65\% акций АВИСМА в г. Березники Пермского края (где и в наши дни выплавляется титановая губка и отправляется в Верхнюю Салду) у группы «Менатеп» М.Б. Ходорковского (группа «Менатеп» еще в ходе приватизации в середине 1990-х гг. собрала 70\% акций АВИСМА, а председателем совета директоров тогда стал М.Б. Ходорковский).

В 1997 г. «Менатеп» уступил свой пакет упомянутому американскому инвестору Кеннету Дарту. Дарт, в свою очередь, поменял пакет на $30 \%$ акций ВСМПО, которое стало владельцем АВИСМА. Затем В.В. Тетюхин и В.И. Брешт выкупили пакет акций Дарта. В скором времени предприятия в Березниках и Верхней Салде перешли на единую акцию, и возникло ВСМПОАВМСМА. Эффективность была налицо, т.к. это позволяло объединить полный производственный цикл, включая изготовление титановой губки (чернового титана).

В марте 1999 г. генеральным директором ОАО «АВИСМА» становится генеральный директор ВСМПО В.В. Тетюхин. Начинает проводиться коренная модернизация энергетического оборудования и реконструируется основное производство. Упорный труд принес заслуженный успех: к 2002 г. березниковские и салдинские металлурги вышли в лидеры титанового производства в мире. Основная часть титана (более 75\%) шла на экспорт в мировой авиапром, оставшаяся часть использовалась в России в оборонной, химической промышленности и энергетике.

Но проблемы у металлургов и лично у В.В. Тетюхина не закончились. Вскоре австрийцы стали претендовать на контрольный пакет акций, а с 2003 г. акции ВСМПО-АВИСМА начали скупать структуры группы компаний «Ренова» В.Ф. Вексельберга. В 2005 г. В.Ф. Вексельберг попытался убедить В.В. Тетюхина и его партнера В.И. Брешта продать ему принадлежавшие им пакеты акций компании. Конфликт акционеров привел к судебным тяжбам и кризису компании.

Вряд ли бы у новых собственников ВСМПО-АВИСМА получилось поднять на новую ступень титановую промышленность России, т.к. это сложнейшее в мире производство. Здесь нужен просто высококлассный профессионализм. А, учитывая его важную роль в ВПК, многие работы еще и в советскую эпоху велись под грифом «секретно», и эти секреты производства оттачивались десятилетиями.

Об одной свой награде сам В.В. Тетюхин вспоминал: «В наградном листе на представление к Ленинской премии сказано, что меня наградили медалью “За трудовую доблесть” в 1962 году за наши первые космические корабли “Восток”. На самом деле это не совсем так. Космос тут присутствовал, но скорее в ином виде. Первые искусственные спутники Земли, вот эти “шарики”, делались из титана. А титан делали мы. За это вот награда». 
Приведем еще одно воспоминание Владислава Валентиновича: «Что касается судостроения, то тут титана шло довольно много. Чего только стоит проект 661 с титановым корпусом!»

Здесь речь идет о советской атомной подводной лодке (К-222), которая имела длину 106,9 м, наибольшую ширину корпуса - 11,5 м, с подводным водоизмещением 7000 т, вооруженной крылатыми ракетами П-70 «Аметист», охранявшей нашу державу с 1968 по 1988 г. (гл. конструктор Н.Н. Исанин, затем - Н.Ф. Шульженко). Она была самой быстрой подводной лодкой в мире. В подводном положении ее скорость достигала 44 узлов (82 км/ч), а надводная скорость - 19 узлов; ее предельная глубина погружения составляла 400 м, и при экипаже в 80 чел. она могла 70 суток находиться в автономном плавании. И это была первая в мире подлодка, оснащенная ракетой подводного старта.

Интересное замечание находим у Владислава Валентиновича и о взаимоотношениях с конструкторами подводных лодок и самолетов: «В целом, надо сказать, продукцию для титановых подводных лодок давали хорошую, каких-то крупных проблем с ней не было. Были разные изделия, трубы для энергетического блока из разных сплавов... И в личном плане отношения были хорошие. Может, этому способствовало то, что не было таких трагедий, как в авиации».

Еще один примечательный факт, связанный с титаном и территорией, где работали наши герои. Алексей Архипович Леонов, человек, который в марте 1965 г. первым в мире вышел в открытый космос, дважды был в гостях у березниковских творцов «крылатого металла» и часто вспоминал людей (конструкторов, инженеров, рабочих), благодаря которым человек вышел в открытый космос.

Тот легендарный полет 1965 г. и трагичен, и символичен. Космический корабль «Восход-2», пилотируемый Павлом Беляевым и Алексеем Леоновым, вынужден был по техническим причинам совершить вынужденную посадку, которая произошла на территории Березниковского городского округа.

В 2004 г. на границе Березников и Усолья, около Камского моста торжественно открывался памятник в честь «внепланового» приземления экипажа «Восход-2». На это мероприятие специально прибыл А.А. Леонов, который уже ранее, в 1977 г., побывал в цехах Березниковского титано-магниевого комбината (БТМК, сегодня - АВИСМА) и беседовал с рабочими и инженерами, которые готовили его полет в космос.

После открытия памятника в 2004 г. Алексей Архипович Леонов, очень общительный и жизнерадостный человек, с присущим ему юмором сказал автору этих строк: «Мы не знали с Пашей (с командиром корабля Павлом Ивановичем Беляевым. - В.Ш.) куда приземлять потерявший автоматическое управление наш корабль... Видимо, березниковская земля, где и был получен для нашего корабля “крылатый” металл, притянула бережно к себе... и все закончилось очень даже хорошо».

Указанные выше «акционерные войны» (2003-2005 гг.) практически парализовали производство: накопились неоплаченные кредиты и долги, износ оборудования достигал 65\%. Для стабилизации ситуации пришлось вмешаться государству (предприятие - главный в стране поставщик титана для оборонной промышленности), и в 2006 г. акционером ВСМПО-АВИСМА становится «Рособоронэкспорт». Тогда и начала выстраиваться новая структура корпоративного управления.

Но еще годом ранее, 1 июля 2005 г., ОАО «АВИСМА титано-магниевый комбинат» было реорганизовано в форме присоединения (с ОАО «Верхнесалдинское металлургическое производственное объединение») к открытому акцио- 
нерному обществу «Корпорация ВСМПО-АВИСМА» и стало именоваться «АВИСМА» - филиал ОАО «Корпорация ВСМПО-АВИСМА».

Объединение двух металлургических производств в единую структуру в Березниках Пермского края и Верхней Салде Свердловской обл. свершилось не просто волевым решением - для этого были все объективные предпосылки, т.к. их производственный цикл имел давнюю связь. Это прекрасно понимал блестящий инженер-металлург Тетюхин и его команда. Тем более, что производство титана - это сложнейший технологический процесс, и даже сегодня он осуществляется только в шести странах (Китай, Япония, Россия, Казахстан, США и Украина).

Технологические и организационные связи березниковского и верхнесалдинского предприятий имели давнюю историю. В.П. Танкеев, который так же, как и В.В. Тетюхин, прошел все ступеньки карьерного роста - от мастера до исполнительного директора АВИСМА - филиала ПАО «Корпорация ВСМПОАВИСМА», не без юмора вспоминал о производственных взаимоотношениях с ВСМПО в советскую эпоху: «Помню абсолютную неуступчивость в вопросах качества титановой губки зам. главного металлурга ВСМПО В.В. Тетюхина. Как-то он в 14 (!) раз подряд отказывался принимать нашу губку, а на 15-й все-таки влепил нам самый настоящий штраф за срыв поставок. Ну, а мы в отместку придумали байку про то, почему это балконы в Верхней Салде так блестят: потому, что салдинцы неизрасходованной березниковской губкой их покрывают! Так мы друг друга подначивали. Но всегда находили общий язык, несмотря на экономические парадоксы и междоусобицы разных министерств, к которым относились БТМК и ВСМПО».

После 1 июля 2005 г. был 3-месячный переходный период, и тогда филиалы возглавили В.П. Танкеев (АВИСМА) и Н.К. Мельников (ВСМПО). Для разработки регламента взаимоотношений между двумя филиалами был создан координационный совет, возглавил который генеральный директор корпорации В.В. Тетюхин.

Таким образом, можно констатировать, что в конце XX - начале XXI в. металлурги г. Березники и г. Верхняя Салда, как и в грозные военные и тяжелые послевоенные годы [Шилов 2020: 14], вновь совершили самый настоящий трудовой подвиг. Они не только спасли титановую промышленность России, но и придали ей новый мощный импульс развития [Запарий 2012: 167], вывели на передовые рубежи в мире [Набойченко 2005]. И, без всякого сомнения, в этом большая заслуга лично В.В. Тетюхина.

После создания в 2007 г. на основе Рособоронэкспорта корпорации «Ростех» (до конца 2012 г. именовалась «Ростехнологии»), контроль над ВСМПОАВИСМА перешел к ней. Сам В.В. Тетюхин считал, что уступить активы он может только государству, а не частным лицам, т.к. был государственником (в хорошем смысле этого слова). Он так говорил по этому поводу: «Жизнь быстротечна, государство вечно!»

В 2012 году журнал Forbes в своем рейтинге 200 богатейших людей России оценивал состояние В.В. Тетюхина в 650 млн долл., при этом называя его не иначе, как «патриархом отечественной титановой отрасли».

Но все свои деньги, вырученные от продажи акций ВСМПО-АВИСМА, В.В. Тетюхин, уже как меценат и филантроп, вложил в строительство Уральского клинического лечебно-реабилитационного центра (его доля инвестиций составила порядка 4 млрд руб.!), в производство титановых имплантатов в Туле и медицинской мебели в Рязани.

Созданная им клиника в Нижнем Тагиле предусматривает ортопедическое лечение, т.е. Владислав Валентинович хотел найти еще одно важное примене- 
ние титана для людей. И до конца своих дней, до 86 лет, В.В. Тетюхин ходил на работу в созданное им детище. Для эффективной работы он собирал по всей стране лучших специалистов-медиков, бился за квоты от Минздрава РФ.

Когда Владислав Валентинович скончался 11 апреля 2019 г., его провожали сначала в Нижнем Тагиле, затем в Верхней Салде. В официальном сообщении ПАО «Корпорация ВСМПО-АВИСМА» о траурном митинге писали: «В почетном карауле в течение всей церемонии стояли начальники цехов... Тысячи салдинцев запустили в небо черные воздушные шары. На протяжении трех часов не иссякал поток жителей Верхней Салды, желающих проститься с Владиславом Валентиновичем Тетюхиным. В скорбной книге памяти сотни людей оставили свои соболезнования».

Экс-губернатор Свердловской области сенатор РФ Э.Э. Россель тогда отметил: «Владислав был богатый человек. Однажды он сказал: “Я не вечный, когданибудь уйду и хочу вложить во что-то полезное свои деньги”. И все свои сбережения вложил в создание больницы. Я не знаю ни одного человека, который сделал бы так же».

Урна с прахом В.В. Тетюхина захоронена в Москве на Ваганьковском кладбище, а созданный В.В. Тетюхиным на собственные деньги Уральский клинический лечебно-реабилитационный центр сегодня носит его имя. Запись об этом уже появилась в Едином государственном реестре юридических лиц. Документ этот обнародовал на заседании Государственной думы РФ депутат А.В. Балыбердин.

Вся яркая профессиональная жизнь В.В. Тетюхина (ученого-металлурга, талантливого организатора производства) была связана с производством титана, а в древнегреческой мифологии утверждается, что могучий титан Атлант держит на своих плечах небесный свод. Образно можно сказать, что так и Владислав Валентинович в трудные для России годы перехода от одного общественного строя к другому на своих плечах со своими коллегами-металлургами держал важную для страны отрасль.

В наши дни ПАО «Корпорация ВСМПО-АВИСМА» производит более $90 \%$ российского титана, экспортирует продукцию в 48 стран мира, имеет около 350 заказчиков. Основные потребители продукции ВСМПО-АВИСМА - не только российские производители, но и крупнейшие в мире двигателе- и авиастроительные компании, в т.ч. Boeing, Airbus, EADS, Embraer, Messier-Bugatti-Dowty, UTAS, Rolls-Royce plc, Safran SA, Pratt\&Whitney и др. И, без всякого сомнения, огромная заслуга в этом лично «патриарха отечественной титановой промышленности» В.В. Тетюхина.

Подводя итог профессиональной и общественной жизни наших героев, следует особо сказать, что личности Ивана Ивановича Любимова и Владислава Валентиновича Тетюхина, их плодотворная деятельность на благо Отечества достойны подражания для тех современных предпринимателей России, которые не замыкаются в рамках своего небольшого бизнеса, а стараются мыслить общегосударственными масштабами, высокими, гуманными, общечеловеческими категориями.

\section{Список литературы}

Ежов А.О. 2014. Титановая промышленность Урала в XX веке: особенности и перспективы развития. - Урал индустриальный. Бакунинские чтения: Индустриальная модернизация Урала в XVIII-XXI вв. Материалы XII Bcepocсийской научной конференции. Екатеринбург, 4-5 декабря 2014 г. В 2 т. Екатеринбург: УрФУ. Т. 2.

Запарий В.В. 2012. Производство титана и магния на Урале в 90-е годы XX века. - Историко-экономические исследования. Т. 13. № 2-3. С. 167-174. 
Набойченко С.С. 2005. Заводы цъетной металлургии Урала. 2-е изд., доп. Екатеринбург: Урал. гос. техн. ун-т - УПИ. 700 с.

Тетюхин В.В. 1993. Верхнесалдинское металлургическое производственное объединение. - Технология легких сплавов. № 6.С. 12-16.

Шилов В.В. 2019. СССР глазами молодежи индустриального города. Социологические исследования. № 4. С. 146-149.

Шилов В.В. 2020. Люди и металлы. БМЗ - БТМК - АВИСМА (авт. идеи Д.В. Трифонов, рук. проекта Е.Ю. Сажина). Екатеринбург. 160 с.

SHILOV Vladimir Viktorovich, Cand.Sci. (Hist.), Associated Professor, Head of the Chair of General Education, Berezniki Branch of Perm National Research Polytechnic University (10 Khimikov St, Berezniki, Perm Region, Russia, 618400; vv5595959@mail.ru); Member of the Board of the Russian Society of Sociologists (Perm Branch)

\title{
THE PHENOMENON OF TWO RUSSIAN OLIGARCHS
}

\section{Part 2}

Abstract. The article considers the professional and social activities of the two richest people in Russia of the pre-Soviet period (I.I. Lyubimov) and the post-Soviet era (V.V. Tetyukhin). The author provides an example of a responsible attitude to social problems of workers and employees of complex industries headed by them, willingness to finance socially significant projects, thinking in both state and high, humane universal categories.

Keywords: initial capital, education, stagnation, economic crisis, effective manager, socially responsible business, patronage, role of individual in history

УДК 323.1(571.54):94

НОМОГОЕВА Виктория Владимировна - доктор исторических наук, доцент исторического факультета Бурятского государственного университета им. Доржи Банзарова (670000, Россия, Республика Бурятия, г. Улан-Удэ, ул. Смолина, 24a; nomogoеva67@таil.ru)

\section{ГОСУДАРСТВЕННАЯ НАЦИОНАЛЬНАЯ ПОЛИТИКА И ЭТНОКУЛЬТУРНОЕ РАЗВИТИЕ БУРЯТИИ В ИСТОРИЧЕСКОЙ РЕТРОСПЕКТИВЕ}

\begin{abstract}
Аннотация. В статье характеризуются сущность и особенности национальной политики государства в национальных регионах России и особенности этнокультурного развития Бурятии на разных этапах своего развития. Автор показывает разнообразие этнокультурного развития народов Бурятии на современном этапе.
\end{abstract}

Ключевые слова: национальная политика, национальные окраины, сибирские этносы, национальная автономия, советский народ, национально-культурное возрождение, этнокультурное развитие, современная Российская Федерация

Dоссийская государственность сложилась на основе полиэтнического и поликультурного консенсуса народов, разных по происхождению, хозяйственным занятиям, образу жизни, вероисповеданию и менталитету. Во мно- 